\title{
The European Crisis of Politics: Ethnoreligious Pluralism and the Rise of Radical Populism and Far-Right in Europe
}

\author{
Cristina Astier \\ mcastier.m@gmail.com \\ Ander Errasti \\ ander.errasti.lopez@gmail.com
}

Globernance Researchers

doi: http://dx.doi.org/10.18543/ced-59-2018pp19-25

\begin{abstract}
It is not highly contentious to claim that the 2008 global economic crisis may be also understood as a failure of the welfare state in European countries. The rise of economic inequalities in Europe, as a major sequel of the 2008 economic crisis and the increase of migrant flows, has fostered and become a breeding ground for racial, religious, or ideological hatred in the western world. However, compared to previous periods in recent history when tensions arose, citizens can now channel their feelings, thoughts, and political ideals through the institutions of the state's basic structure. Thus, citizens are having a say by channelling their claims through democratic means and different forms of political participation. One relevant articulation has been new expressions of radical populism, nativism, and far-right ideologies which have burst into the public sphere, at the local, regional, and European levels. This combination has turned the economic and refugee crisis into what is mainly a crisis of European politics.

Keywords: European integration, political crisis, democratic challenges, rise of radicalisms, united in diversity.
\end{abstract}

It is not very controversial to affirm that Europe is facing a critical period: the aftermath of the 2008 economic crisis is proving to be a challenge beyond economic frontiers. At the institutional level, the democracies of both member states and the European Union are failing to adequately address these unintended consequences. Increasing fear, the sense of insecurity both within and among countries, and economic and social uncertainties resulting from the crisis are changing the political scenario throughout Europe. It might be said that the unfair distribution of the costs, economic and otherwise, of this last crisis has pushed citizens in different European 
countries to break up with both European foundational values and the traditional sources of social cohesion, including traditional political parties, the media, expert authority, or public domestic, European, and international institutions.

These western phenomena coincided with the aftermath both of the Arab Spring and the second Iraq War which have, broadly, descended into political instability and, ultimately, several international military conflicts in the regions adjoining the European Union. In the particular case of the Syrian civil war, which began in 2011, an increasing number of refugees avoiding the conflict joined economic migrant persons coming from North African regions to Europe. Nowadays, it is estimated that the total number of Syrian refugees is around 11 million people since the beginning of the war in 2011 while 13.5 million are in need of humanitarian assistance inside the country, including difficult to reach zones. Among these people, almost one million have requested asylum in Europe. Although there was a commitment to grant asylum among member states in the European Union, neither those states nor the European Union's particular institutions managed to give an adequate response to the impact of this so-called refugee crisis. In this sense, and particularly in the case of Syrian refugees, an urgent challenge such as social integration of migrant persons has not been adequately addressed in European member states.

In this scenario, both the rise of economic inequalities in the aftermath of the 2008 economic crisis, which may be understood as a failure of the welfare state in European countries, and the increase of migrant flows fostered and are a breeding ground for racial, religious, or ideological hatred in the western world. In this case, the distinct feature, compared to previous periods when tensions arose, is that citizens can use political tools to channel their feelings, thoughts, and political ideals. Citizens are having a say by channelling their claims through democratic means and different forms of political participation. One relevant articulation has been new expressions of radical populism, nativism, and far-right ideologies which have burst into the European public sphere, at the local, regional, and European levels. This combination has turned the economic and refugee crisis into what is also and mainly a crisis of European politics.

This volume of the CED (Cuadernos Europeos de Deusto) is the result of the International Workshop on the European Crisis of Politics: Ethnoreligious Pluralism and the Rise of Radical Populism, Nativism and the Far-right in Europe organised by the Institute of Democratic Governance (Globernance) on June $16^{\text {th }}, 2017$, at the San Telmo Museum in DonostiaSan Sebastián. Following the event's path, this publication aims to address 
and disentangle some of the key dimensions of this world-wide phenomena. It analyses, in a first set of articles by Carmen Innerarity and Sergio García, the exact meaning of Ethnoreligious Pluralism in Europe and the principles that should guide the way European institutions address it. The volume continues, with articles by Beatriz Acha and Dídac Gutiérrez-Peris, focuses on the radicalised socio-political reactions vis-á-vis this transformation, analysing how these socio-political movements have engaged with electorates, including the impact of fear in political decisions. The volume concludes with an article by Joxerramon Bengoetxea that addresses how these elements of the European crisis of politics imply a challenge for both the European integration process and the maintenance of European foundational values such as solidarity and liberal constitutional democracy.

The volume begins with a preface by Alexander Görlach, affiliate professor with the F. D. Roosevelt Foundation's "In Defense of Democracy"Program at Adams House, Harvard University College. With his global understanding and experience of democracy, Professor Görlach provides an insightful overview on the main challenges that illiberal and counter-cosmopolitan political forces are posing to European democracy.

Next, the volume introduces an article by Carmen Innerarity, lecturer in Sociology at the Public University of Navarra, entitled Illiberal Secularism: Faking Inclusion Through Neutrality. This paper analyses how secularism, despite its universalist and inclusive vocation, has become the main argument for the exclusion of Muslim religious practices, with the consequent limitation of individual liberties. Thus, an institution that is perceived as a guarantee of the equality of citizens through the differentiation of the political and religious spheres comes to define the identity of the peoples of Europe, demanding a defence against the accommodation demands raised by Muslim immigrants. Obviously, it is not possible to establish a cause-effect relationship, but the climate of hostility toward the cultural difference spread by the entry into several European polities of radical right parties, clearly hostile to Islam and Muslims, could be influencing, in some way, the political orientation of European governments in this regard.

In line with that first reflection, the volume includes a review of the ongoing social secularization process presented by Sergio García, teachingresearcher at the Camilo José Cela University and the CEDEU / Rey Juan Carlos, titled Secularization, Liberalism and The Problematic Role of Religion in Modern Societies. This paper argues that there is a defective understanding of the sociological secularization process and a liberal tradition that takes for granted many problematic notions and subtly determines the logic of the debate on religion in modern societies. While the two issues 
are not causal factors for the rise of radical right-wing populist movements, they constitute the theoretical framework within which the debates on ethno-religious pluralism and its relationship with politics take place. These two unresolved questions hinder a good understanding of the complexity of social phenomena related to religion in contemporary Western societies such as fundamentalism, terrorism, political Islam, or the claims of other religious groups to participate in the public sphere. To develop this analysis, the article focuses on four interconnected points. The first briefly reviews secularization theory and secularism as an ideology. The second constitutes a questioning of the liberal theoretical framework. The third proposes a particular way of approaching those social phenomena linked to religion. The paper concludes by broadly examining the main features related to religion that feed right-wing populist movements.

A second pair of articles begins by introducing an article by Beatriz Acha, assistant-lecturer at the Public University of Navarra, entitled The Far Right in Western Europe: "From the Margins to the Mainstream" and Back? This paper analyses the rise of far-right political movements in Western Europe and the widespread political, social, and scholarly concern raised by the right-wing extremist parties' recent electoral performances. The paper departs from the understanding that, since the late 1980s, we are on a new (third) "wave" of right-wing extremism in several European countries - with some extremist parties already undergoing electoral and political consolidation. This paper joins the myriad contributions that have approached the issue of the "mainstreaming" of these extremist parties since the beginning. It presents some data on the far right's electoral and political evolution, which seem to confirm that some mainstreaming did take place in the decades between the 1980s and the 2000s. The paper continues to introduce the key features of a different and more recent phase in the far right's political evolution: the immigration issue - the Far Right's topic par excellence-linked to the "refugee crisis", which has prompted the radicalization of many (if not all) of the Far Right parties (and even of some parties which were not thought to be extremist). The paper reflects on this process of alleged radicalization of the Far Right. The conclusion speculates on the future evolution of the Far Right and highlights future avenues for research.

The second article of this set, New Realignment of Fears in France and Europe, is related to the same topic but focused on one of the key factors that explains this political phenomenon: the increasing relevance of fear in European politics and its consequences for democracy. Dídac Gutiérrez-Péris, lecturer at the Public Affairs School at Sciences Po Paris and Research Director at Viavoice, bases the article primarily on a study conducted throughout 2016 in France, Poland, the UK, Spain, Sweden, and 
Germany with the think tank Demos and the Institute Notre Europe - Institut Jacques Delors, called 'Nothing to Fear but Fear Itself'. The paper focuses mainly on France and departs from the statement that we are living a sort of backlash against the 'multiculturalist' approach to integration. This paper points out three of the most common symptoms regarding the new alignment of fears in Europe. It suggests that Europe is not only witnessing a rise of fearful attitudes about terrorism or uncertainty, but also the rise of a society that shows signs of exhaustion regarding the values that used to be the bed stone of European openness. The three symptoms described are: i) growing support for authoritarian populist parties, ii) a low and failing trust in political institutions, and iii) a hardening of social attitudes regarding immigration and diversity. As shown throughout the paper, this cannot always be linked to some of the new fears European societies are facing, but it is the necessary contextual starting point when analysing one of those new fears, namely the hardening of social attitudes on immigration and diversity.

Finally, Joxerramon Bengoetxea, Professor at the University of the Basque Country (UPV/EHU), provides a wider reflection about An Existential Crisis? Freedom, Tolerance, Solidarity, Peace; or, Why Europe Is Valuable. The paper addresses Europe's existential crisis by suggesting that, notwithstanding the relevance of institutional design, the essence of the project of European integration is persons and peoples rather than states. This idea is exemplified in the speeches of two important personalities who addressed Europe's existential crisis. Finally, the paper focuses on the question of diversity since the motto of the failed constitutional treaty was precisely "united in diversity", which requires an explanation of the centrality of the individual in practical reason and the importance of normative systems. The centrality of the individual, related to the value of freedom, is then placed in the context of plurality and diversity, directly addressing the theme of backlash forces in Europe through a map of plurality in the continent: the so-called multiculturalism or ethno-religious pluralism. The paper concludes by suggesting a version of cosmopolitanism, hermeneutic pluralism, as the normative position to address the balance between individual freedom and solidarity or between "persons" and "peoples".

As a last note, we would like to acknowledge the participants at the International Workshop on the European Crisis of Politics: Ethnoreligious Pluralism and the Rise of Radical Populism, Nativism and the Far-right in Europe organised by the Institute of Democratic Governance (Globernance) on June 16th, 2017, at the San Telmo Museum in Donostia-San Sebastián. Without their contributions, comments and fruitful debates this publication would not have been possible. Notably, we would like to thank Professor 
Daniel Innerarity for his coordination and Mikel Cabello for his precious support. Besides, Sandra Kingery has done a magnificent work languagereviewing the articles. Finally, we would like to show our gratitude to all the team at Deusto Journal of European Studies, with a special acknowledgement for professor Beatriz Pérez de las Heras and her firm belief in this endeavour. Any virtues on this issue are the result of combining all of their contributions, while any faults are just attributable to our errors.

\section{About the authors}

Ander Errasti holds a PhD in Humanities - Ethics and Political Philosophy - from UPF, supervised by Dr Sonia Arribas and Dr Daniel Innerarity. His research focused on a normative analysis of Ulrich Beck's Cosmopolitanism ("Nations and Nationalism in a Cosmopolitanized World: Some Lessons from Ulrich Beck's Work"). He has been a Visiting Doctoral Student at the Department of Politics and International Relations at Oxford University. BA in Philosophy at University of Barcelona (UB), MA in Political Philosophy at the Pompeu Fabra University (UPF), Business Administration Diploma at UB, Advanced LLM in Legal Sciences at the UPF. He has been working at the Basque Institute of Democratic Governance since 2013, where he has organised several conferences, publications, and research activities. He is currently developing a research project in cooperation with the University of Edinburgh (supervised by Professors Michael Keating and Nicola McEwan) on the impact of Brexit and the 2014 independence referendum on Scotland's self-government institutions. Finally, Errasti is a member of the GISME group at the UB since 2010, directed by Professor Javier Tejada. In that capacity, he has organised several dissemination activities, including collaborations with the Prado Museum, the Spanish Foundation of Science and Technology, or Jakiunde (the Basque Academy of Science and Humanities). He is the Coordinator Assistant of the "CCentre: Towards Citizen Centered Active Ageing and Well Being" project (2016-2019) financed by the EIT Health and Coordinated by Professor Elena Lauroba. He was the Project Manager of the European Commission funded SIforAGE Project on Social Innovation for Active and Healthy Ageing for Sustainable Economic Growth (2013-2016).

Cristina Astier is a $\mathrm{PhD}$ student in Political Philosophy at the Universitat Pompeu Fabra (Barcelona), a researcher at Globernance (Institute for Democratic Governance in San Sebastián) and a researcher at GISME (Group on Innovative Mathematical Solutions for Entities), a multidisci- 
plinary group of the University of Barcelona. She graduated with a BA in philosophy from the University of Barcelona and a Master's degree in political philosophy from Pompeu Fabra University. She has been a PhD visiting student at the Department of Politics and International Relations and at the Centre for the Study of Social Justice at Oxford University. Her research focuses on issues of global ethics, global distributive justice, justice in international trade and consumption, and the legitimacy of global governance institutions. Astier combines academic work with non-academic professional activities, especially in European funded projects. From 2012 to 2016, she was the coordinator assistant and head of communications of the European project SIforAGE (Social Innovation for Active and Healthy Ageing) funded under the 7th Framework Programme by the European Commission. Since 2016, she is the content and communications manager of the European project Ccentre. The project is funded by EIT (European Institute of Innovation \& Technology) Health, a body of the European Union. 


\section{Derechos de autor}

Los derechos de autor (para la distribución, comunicación pública, reproducción e inclusión en bases de datos de indexación y repositorios institucionales) de esta publicación (Cuadernos Europeos de Deusto, CED) pertenecen a la editorial Universidad de Deusto. El acceso al contenido digital de cualquier número de Cuadernos Europeos de Deusto es gratuito inmediatamente después de su publicación. Los trabajos podrán leerse, descargarse, copiar y difundir en cualquier medio sin fines comerciales y según lo previsto por la ley; sin la previa autorización de la Editorial (Universidad de Deusto) o el autor. Así mismo, los trabajos editados en CED pueden ser publicados con posterioridad en otros medios o revistas, siempre que el autor indique con claridad y en la primera nota a pie de página que el trabajo se publicó por primera vez en $C E D$, con indicación del número, año, páginas y DOI (si procede). Cualquier otro uso de su contenido en cualquier medio o formato, ahora conocido o desarrollado en el futuro, requiere el permiso previo por escrito del titular de los derechos de autor.

\section{Copyright}

Copyright (for distribution, public communication, reproduction and inclusion in indexation databases and institutional repositories) of this publication (Cuadernos Europeos de Deusto, CED) belongs to the publisher University of Deusto. Access to the digital content of any Issue of Cuadernos Europeos de Deusto is free upon its publication. The content can be read, downloaded, copied, and distributed freely in any medium only for non-commercial purposes and in accordance with any applicable copyright legislation, without prior permission from the copyright holder (University of Deusto) or the author. Thus, the content of $C E D$ can be subsequently published in other media or journals, as long as the author clearly indicates in the first footnote that the work was published in $C E D$ for the first time, indicating the Issue number, year, pages, and DOI (if applicable). Any other use of its content in any medium or format, now known or developed in the future, requires prior written permission of the copyright holder. 